\title{
KEDUDUKAN NOTARIS SEBAGAI PEJABAT UMUM DALAM PERSPEKTF UNDANG-UNDANG JABATAN NOTARIS
}

\author{
M. Syahrul Borman \\ Fakultas Hukum Unversitas Doktor Soetomo \\ J1. Semolowaru No.84, Menur Pumpungan, Sukolilo, Surabaya \\ Email:m.syarul.borman@unitomo.ac.id
}

\begin{abstract}
Abstrak
Kedudukan notaris sangat strategis, karena notaris adalah pejabat umum yang diangkat oleh pemerintah atau negara, disamping mempunyai kewenangan dalam membuat atau menerbitkan akta autentik. Akta autenik yang dibuat oleh notaris inilah yang membuat notaris menjadi salah satu pelaksana profesi hukum yang banyak berpengaruh terhadap banyak hal yang berhubungan dengan dunia hukum dan layanan masyarakat. Kewenangan notaris ini pula yang membuat masyarakat atau pemohon, khususnya para pemohon layanan jasa pembuatan akta perjanjian bergantung pada pelaksanaan profesinya.
\end{abstract}

Kata kunci: kedudukan, notaris, kewenangan, profesi, pelaksanaan

\section{Abstract}

The position of the notary is very strategic, because the notary is a public official appointed by the government or the state, besides having the authority to make or issue authentic deeds. This authentic deed made by a notary makes a notary become one of the executors of the legal profession that has a lot of influence on many matters relating to the world of law and public services. The authority of this notary also makes the community or the applicant, especially the applicants for the service of making an agreement deed dependent on the implementation of their profession. Keywords: position, notary, authority, profession, implementation

\section{PENDAHULUAN}

Van Apeldoorn dalam bukunya "Inleiding tot de studie van het Nederlandserecht" mengatakan, bahwa tujuan hukum ialah mengatur pergaulan hidup manusia secara damai. Hukum menghendaki perdamaian. ${ }^{1}$ Hukum yang dikehendaki ini merupakan produk hukum yang normanormanya mengatur kehidupan individu manusia di tengah pergaulatan hidupnya, sehingga antar individu bisa saling menghargai, menghormati,

1 K. Kholilurrahman, Membangun Penegakan Hukum yang Beradab, (Jakarta: Tinta Mas, 2013), hal. 3, 
menciptakan kedamaian, atau mewujudkan penegakan kewajiban dan hakhaknya.

Salah satu tokoh sosiologi hukum yang menyampaikan pemikiran tentang hukum adalah Soerjono Soekanto. Menurut Soerjono Soekanto ${ }^{2}$ ini, hukum memiliki beberapa terjemahan: bahwa 1) hukum sebagai ilmu pengetahuan, yakni pengetahuan yang tersusun secara sistematis atas dasar kekuatan pemikiran. 2) hukum sebagai disiplin, yakni suatu sistem ajaran tentang kenyataan atau gejala-gejala yang dihadapi. 3) hukum sebagai kaedah, yakni pedoman atau patokan sikap tindak atau perikelakuan yang pantas atau diharapkan. 4) hukum sebagai lembaga sosial (social institution) yang merupakan himpunan dari kaedah-kaedah dari segala tingkatan yang berkisar pada kebutuhan pokok didalam kehidupan masyarakat. 5) hukum sebagai tata hukum, yakni struktur dan proses perangkat kaedah-kaedah hukum yang berlaku pada suatu waktu dan tempat tertentu, serta berbentuk tertulis. 6) hukum sebagai petugas, yakni pribadi-pribadi yang merupakan kalangan yang berhubungan erat dengan penegak hukum. 7) hukum sebagai keputusan penguasa, yakni hasil proses diskresi yang menyangkut pengambilan keputusan yang didasarkan pada hukum, akan tetapi yang didasarkan juga atas penilaian pribadi. 8) hukum sebagai proses pemerintahan, yaitu proses hubungan timbal balik antara unsur-unsur pokok dari sistem kenegaraan. 9) hukum sebagai sarana sistem pengendalian sosial yang mencakup segala proses baik direncanakan maupun tidak, yang bertujuan untuk mendidik, mengajak atau bahkan memaksa warga masyarakat (dari segala lapisan) agar mematuhi kaedah-kaedah dan nilainilai. 10) hukum sebagai sikap tindak atau perikelakuan yang runtut, yaitu perikelakuan yang diulang-ulang dengan cara yang sama, yang bertujuan untuk mencari kedamaian. 11) hukum sebagai jalinan nilai-nilai baru, yaitu dari konsepsi-konsepsi abstrak dalam diri manusia tentang apa yang dianggap baik (sehingga harus dianuti atau ditaati) dan apa yang dianggap buruk (sehingga harus dihindari), dan 12) hukum sebagai seni.

Thomas Hobbes dalam "Leviathan" menyebut hukum adalah perintahperintah dari orang yang memiliki kekuasaan untuk memerintah dan memaksakan perintahnya kepada orang lain, Rudolf von Jhering dalam "Der Zweck Im Recht" 1877-1882 menyebut hukum adalah keseluruhan peraturan yang memaksa yang berlaku dalam suatu negara. Plato berpendapat hukum merupakan peraturan-peraturan yang teratur dan tersusun baik yang mengikat masyarakat. Aristoteles berpendapat, bahwa hukum hanya sebagai kumpulan peraturan yang tidak hanya mengikat masyarakat tetapi juga hakim. Abdulkadir Muhammad menyatakan hukum adalah segala peraturan

${ }^{2}$ Soerjono Soekanto, Faktor-faktor yang Mempengaruhi Penegakan Hukum di Indonesia, (Jakarta: Rajawali Pres, 1988) hal. 15-16. 
tertulis dan tidak tertulis yang mempunyai sanksi yang tegas terhadap pelanggarnya. ${ }^{3}$

Mochtar Kusumaatmadja berpendapat, bahwa pemahaman hukum yang memadai harus tidak hanya memandang hukum itu sebagai suatu perangkat kaidah dan asas-asas yang mengatur kehidupan manusia dalam masyarakat, tapi harus pula mencakup lembaga (institusi) dan proses yang diperlukan untuk mewujudkan hukum itu dalam kenyataan. ${ }^{4}$

Salah satu norma yuridis yang diproduk oleh negara adalah UndangUndang Republik Indonesia Nomor 2 Tahun 2014 Tentang Perubahan Atas Undang-Undang Nomor 30 Tahun 2004 Tentang Jabatan Notaris. Norma yuridis ini dibuat untuk mengatur profesi notaris dala menjalankan kewenangannya. Kewenangan ini perlu diatur karena dapat berimplikasi pada banyak aspek yang berhubungan dengan kepentingan masyarakat.

Pengaturan itu bukan hanya penting bagi notaris, tetapi juga masyarakat, karena masyarakat atau manusia merupakan subyek hukum yang berhubungan dengan notaris, yang berasal dari konstruksi hubungan ini menimbulkan kewajiban dan hak. Meskipun demikian, masih rentan muncul problematika antara kewenangan notaris dalam hubungannya dengan kepentingan masyarakat (penghadap).

\section{PEMBAHASAN}

Istilah Notaris dapat dijumpai dalam berbagai norma atau pendapat ahli. Notaris disebut sebagai pejabat umum. Pejabat Umum merupakan terjemahan dari istilah openbare amtbtenaren yang terdapat dalam Pasal 1 Peraturan Jabatan Notaris (PJN) dan Pasal 1868 KUHPdt. Berdasarkan pengertian tersebut di atas, bahwa notaris berwenang membuat akta sepanjang dikehendaki para pihak atau menurut aturan hukum wajib dibuat dalam bentuk akta autentik. Pembuatan akta tersebut harus berdasarkan aturan hukum yang berkaitan dengan prosedur pembuatan akta notaris, sehingga Jabatan Notaris sebagai Pejabat Umum tidak perlu lagi diberi sebutan lain yang berkaitan dengan kewenangan notaris.

Jabatan notaris disebutkan dalam Pasal 1 UU Jabatan Notaris (selanjutnya UUJN) yang menyatakan bahwa: Notaris adalah pejabat umum yang satu-satunya berwenang untuk membuat akta autentik mengenai semua perbuatan, perjanjian dan penetapan yang diharuskan oleh suatu peraturan umum atau oleh yang berkepentingan dikehendaki untuk dinyatakan dalam suatu akta autentik, menjamin kepastian tanggalnya, menyimpan aktanya,

${ }^{3}$ K. Kholilurrahman, Op.Cit., hal. 4.

${ }^{4}$ Penelitian "Konstruksi Perwakilan Daerah Dalam Sistem Ketatanegaraan Indonesia”, Kerjasama DPD RI dan Universitas Brawijaya, (Malang: Pusat Pengkajian Konstitusi Fakultas Hukum Universitas Brawijaya, 2009), hal. 15. 
dan memberikan grosse, salinan dan kutipannya, semuanya sepanjang pembuatan akta itu oleh suatu peraturan umum tidak juga ditugaskan atau dikecualikan kepada pejabat atau orang lain.

Kata notaris berasal dari kata "nota literaria" yaitu tanda tulisan atau karakter yang dipergunakan untuk menuliskan atau menggambarkan ungkapan kalimat yang disampaikan nara sumber. Tanda atau karakter yang dimaksud adalah tanda yang dipakai dalam penulisan cepat (stenografie). ${ }^{5}$

Pada awalnya jabatan notaris hakikatnya adalah sebagai pejabat umum (private notary) yang ditugaskan oleh kekuasaan umum untuk melayani kebutuhan masyarakat akan alat bukti autentik yang memberikan kepastian hubungan hukum keperdataan. Jadi, sepanjang alat bukti autentik tetap diperlukan oleh sistem hukum negara maka jabatan notaris akan tetap diperlukan eksistensinya di tengah masyarakat.

Notaris seperti yang dikenal di zaman "Republik der Verenigde Nederlanden" mulai masuk di Indonesia pada permulaan abad ke-17 dengan beradanya "Oost Ind. Compagnie" di Indonesia. ${ }^{6}$ Masuknya ini tidak lepas dari kebutuhan setiap masyarakat, khususnya masyarakat Indonesia terhadap kepastian hokum dalam pengelolaan, diantaranya berkaitan dengan pendaftaran tanah. ${ }^{7}$

Pada tanggal 27 Agustus 1620, yaitu beberapa bulan setelah dijadikannya Jacatra sebagai ibukota (tanggal 4 Maret 1621 dinamakan "Batavia"), Melchior Kerchem, Sekretaris dari "College van Schepenen" di Jacatra, diangkat sebagai notaris pertama di Indonesia. Di dalam akta pengangkatan Melchior Kerchem sebagai notaris sekaligus secara singkat dimuat suatu instruksi yang menguraikan bidang pekerjaan dan wewenangnya, yakni untuk menjalankan tugas jabatannya di kota Jacatra untuk kepentingan publik. Kepadanya ditugaskan untuk menjalankan pekerjaannya itu sesuai dengan sumpah setia yang diucapkannya pada waktu pengangkatannya di hadapan Baljuw di Kasteel Batavia. ${ }^{8}$

Notaris adalah pejabat umum yang satu-satunya berwenang untuk membuat akta otentik mengenai semua perbuatan, perjanjian dan penetapan yang diharuskan oleh suatu peraturan umum atau oleh yang berkepentingan dikehendaki untuk dinyatakan dalam suatu akta autentik, menjamin kepastian tanggalnya, menyimpan aktanya dan memberikan grosse, salinan

${ }^{5}$ G.H.S. Lumban Tobing, Peraturan Jabatan Notaris (Notaris Reglement), )Jakarta: Erlangga, 1980), hal. 41

${ }^{6}$ G.H.S. Lumban Tobing, Peraturan Jabatan Notaris, cet. 3, (Jakarta: Erlangga, 1983), hal. 15

${ }^{7}$ Hizbul Maulana, Masyarakat Indonesia Membutuhkan Notaris (Jakarta: Primamedia, 2015), hal. 5.

${ }^{8}$ G.H.S. Lumban Tobing, Op.Cit, hal. 31 
dan kutipannya, semuanya sepanjang pembuatan akta itu oleh suatu peraturan umum tidak juga ditugaskan atau dikecualikan kepada pejabat atau orang lain. ${ }^{9}$

Menurut Peraturan Menteri Hukum dan Hak Asasi Manusia RI No. M.01-HT.03.01 Tahun 2006, tentang Syarat dan Tata Cara Pengangkatan dan Pemindahan, dan Pemberhentian Notaris, dalam Pasal 1 ayat (1), yang dimaksud dengan Notaris adalah pejabat umum yang berwenang untuk membuat akta autentik dan kewenangan lainnya, sebagaimana dimaksud dalam Undang-Undang Jabatan Notaris (UUJN).

Notaris adalah pejabat umum maksudnya adalah seseorang yang diangkat, diberi wewenang dan kewajiban oleh negara untuk melayani publik dalam hal tertentu. Hal ini menunjukkan peran negara yang menentukan posisi atau eksistensi notaris. Tanpa campur tangan negara, tidak akan pernah ada norma yuridis yang memberikan otoritas pada notaris.

Notaris merupakan pejabat publik yang menjalankan profesi dalam pelayanan hukum kepada masyarakat, guna memberi perlindungan dan jaminan hukum demi tercapainya kepastian hukum dalam masyarakat. Pejabat umum adalah orang yang menjalankan sebagian fungsi publik negara, yang khususnya di bidang hukum perdata. Bahwa untuk membuat akta autentik, seseorang harus mempunyai kedudukan sebagai "pejabat umum".

Berdasarkan pengertian-pengertian Notaris diatas ada hal penting yang tersirat, yaitu ketentuan dalam permulaan pasal tersebut, bahwa Notaris adalah pejabat umum dimana kewenangannya atau kewajibannya yang utama ialah membuat akta-akta autentik, jadi Notaris merupakan pejabat umum sebagaimana yang dimaksud pada Pasal 1868 KUHPerdata.

Pengertian Notaris Menurut pengertian Undang-Undang No. 30 Tahun 2004 tentang Jabatan Notaris (sudah diubah dengan Undang-undang baru, yakni Undang-Undang Republik Indonesia Nomor 2 Tahun 2014 Tentang Perubahan Atas Undang-Undang Nomor 30 Tahun 2004 Tentang Jabatan Notaris) yang dalam Pasal 1 UU ini disebutkan pengertian Notaris adalah pejabat umum yang berwenang untuk membuat akta autentik dan kewenangan lainnya sebagaimana dimaksud dalam Undang-Undang ini.

Dalam Penjelasan Undang-Undang Republik Indonesia Nomor 2 Tahun 2014 Tentang Perubahan Atas Undang-Undang Nomor 30 Tahun 2004 Tentang Jabatan Notaris disebutkan, bahwa Negara Republik Indonesia sebagai negara hukum berdasarkan Pancasila dan UndangUndang Dasar Negara Republik Indonesia Tahun 1945 menjamin kepastian, ketertiban, dan perlindungan hukum bagi setiap warga negara. Untuk

\section{${ }^{9}$ ibid.}


menjamin kepastian, ketertiban, dan perlindungan hukum dibutuhkan alat bukti tertulis yang bersifat autentik mengenai perbuatan, perjanjian, penetapan, dan peristiwa hukum yang dibuat di hadapan atau oleh Notaris. Notaris sebagai pejabat umum yang menjalankan profesi dalam memberikan jasa hukum kepada masyarakat, perlu mendapatkan perlindungan dan jaminan demi tercapainya kepastian hukum. Jaminan perlindungan dan jaminan tercapainya kepastian hukum terhadap pelaksanaan tugas Notaris telah diatur dalam Undang-Undang Nomor 30 Tahun 2004 tentang Jabatan Notaris. Namun, beberapa ketentuan dalam Undang-Undang tersebut sudah tidak sesuai lagi dengan perkembangan hukum dan kebutuhan masyarakat sehingga perlu dilakukan perubahan, yang juga dimaksudkan untuk lebih menegaskan dan memantapkan tugas, fungsi, dan kewenangan Notaris sebagai pejabat yang menjalankan pelayanan publik, sekaligus sinkronisasi dengan undang-undang lain.

Syarat untuk dapat diangkat menjadi Notaris sebagaimana diatur dalam Pasal 3 Undang-Undang No. 30 Tahun 2004 tentang Jabatan Notaris (sudah diubah dengan Undang-undang baru, tetapi syarat ini tidak mengalami perubahan $)^{10}$ adalah:

1) Warga negara Indonesia;

2) Bertakwa kepada Tuhan Yang Maha Esa;

3) Berumur paling sedikit 27 tahun;

4) Sehat jasmani dan rohani;

5) Berijazah sarjana hukum dan lulusan jenjang strata dua kenotariatan;

6) Telah menjalani magang atau nyata-nyata telah bekerja sebagai karyawan Notaris dalam waktu 12 bulan berturut-turut pada kantor Notaris atas prakarsa sendiri atau atas rekomendasi Organisasi Notaris setelah lulus strata dua kenotariatan; dan

7) Tidak berstatus sebagai pegawai negeri, pejabat negara, advokat, atau tidak sedang memangku jabatan lain yang oleh Undang-Undang dilarang untuk dirangkap dengan jabatan Notaris.

Dari sisi sejarah, semula dikenal pejabat umum. Istilah pejabat umum merupakan terjemahan dari istilah Openbare Ambteneran yang terdapat dalam pasal 1868 KUHPerdata. Pasal 1868 KUHPerdata menyebutkan: "Eene authentieke acte is de zoodanige welke in de wettelijken vorn is verleden, door of ten overstaan van openbare ambtenaren die daartoe bevoegd zijn ter plaatse alwaar zuiks is geschied" (suatu akta autentik ialah suatu akta yang dibuat dalam bentuk yang ditentukan undang-undang oleh atau di hadapan pejabat umum yang berwenang untuk itu di tempat akta itu dibuat).

${ }^{10}$ Undang-Undang Republik Indonesia Nomor 2 Tahun 2014 Tentang Perubahan Atas Undang-Undang Nomor 30 Tahun 2004 Tentang Jabatan Notaris 
Openbare Ambtenaren yang diterjemahkan sebagai Pejabat Umum diartikan sebagai pejabat yang diserahi tugas untuk membuat akta autentik yang melayani kepentingan publik, dan kualifikasi seperti itu diberikan kepada Notaris. Maka berdasarkan ketentuan Pasal 1868 Kitab UndangUndang Hukum Perdata tersebut, untuk dapat membuat suatu akta autentik seseorang harus mempunyai kedudukan sebagai pejabat umum. Namun dalam Pasal 1868 itu tidak menjelaskan lebih lanjut mengenai siapa yang dimaksud sebagai pejabat umum tersebut.

Menurut kamus hukum salah satu arti dari Ambtenaren adalah Pejabat. Dengan demikian openbare ambtenaren adalah pejabat yang mempunyai tugas yang bertalian dengan kepentingan publik, sehingga tepat jika openbare ambtenaren diartikan sebagai Pejabat Publik. Khusus berkaitan dengan openbare ambtenaren yang diterjemahkan sebagai Pejabat Umum diartikan sebagai pejabat yang diserahi tugas untuk membuat akta autentik yang melayani kepentingan publik, dan kualifikasi seperti itu diberikan kepada Notaris.

Menurut Pasal 1 Undang Undang Nomor 30 tahun 2004 disebutkan definisi notaris, bahwa notaris adalah pejabat umum yang berwenang untuk membuat akta autentik dan kewenangan lainnya sebagaimana maksud dalam Undang-Undang ini. Pengertian ini dapat dibandingkan dengan pengertian lain dalam Undang-Undang Republik Indonesia Nomor 2 Tahun 2014 Tentang Perubahan Atas Undang-Undang Nomor 30 Tahun 2004 Tentang Jabatan Notaris yang menyebutkan, bahwa notaris adalah pejabat umum yang berwenang untuk membuat akta autentik dan kewenangan lainnya sebagaimana dimaksud dalam Undang-Undang ini.

Dalam produk yuridis yang mengatur perubahan tersebut, ada hal yang sama, yakni berkaitan dengan kedudukan notaris sebagai pejabat umum dan kewenangannya yang berhubungan dengan pembuatan akta. Jabatan notaris ini identik dengan memberikan kewenangan padanya dalam pembuatan akta autentik.

Berdasarkan rumusan UUJN tersebut, maka dapat dipahami, bahwa pejabat umum adalah orang yang menjalankan sebagian fungsi publik dari negara, khususnya di bidang hukum perdata. Pejabat umum adalah seseorang yang diangkat dan diberhentikan oleh pemerintah dan diberi wewenang dan kewajiban untuk melayani publik dalam hal-hal tertentu karena ia ikut serta melaksanakan suatu kekuasaan yang bersumber pada kewibawaan dari pemerintah. Dalam jabatannya tersimpul suatu sifat atau ciri khas yang membedakannya dan jabatan-jabatan lainnya dalam masyarakat.

Sebagai pejabat umum, notaris diangkat oleh Menteri untuk melaksanakan sebagian fungsi publik dari negara dan bekerja untuk 
pelayanan kepentingan umum khususnya dalam bidang hukum perdata, walaupun notaris bukan merupakan pegawai negeri yang menerima gaji dari Negara. Pelayanan kepentingan umum tersebut adalah dalam arti bidang pelayanan pembuatan akta dan tugas-tugas lain yang dibebankan kepada notaris, yang melekat pada predikat sebagai pejabat umum dalam ruang lingkup tugas dan kewenangan notaris.

Akta notaris yang diterbitkan oleh notaris memberikan kepastian hukum bagi masyarakat. Menurut Nusyirwan notaris adalah orang semi swasta, karena ia tidak bisa bertindak bebas sebagaimana seorang swasta. Ia harus menjunjung tinggi martabatnya, oleh karena itu ia diperkenankan menerima uang jasa (honorarium) untuk setiap pelayanan yang diberikannya. ${ }^{11}$

"Honorarium" berasal dan kata latin honor yang artinya kehormatan, kemuliaan, tanda hormat/ penghargaan semula mengandung pengertian balas jasa para nasabah atau klien kepada dokter, akuntan, pengacara, dan notaris. ${ }^{12}$ Balas jasa inilah yang seringkali menjadi ujian utama dari kewenangan notaris, karena balas jasa ini leih identic dengan pembayaran yang disepakati dari awal antara notaris dengan kliennya.

Di Indonesia para notaris berhimpun dalam sebuah wadah perkumpulan yang bernama I.N.I. I.N.I merupakan perkumpulan notaris yang legal dan sudah berbadan hukum sesuai dengan SK Menteri Kehakiman Republik Indonesia Tanggal 23 Januari 1995 Nomor C210221.HT.01.06. Sebagai organisasi perkumpulan notaris, INI menaungi kegiatan praktik notaris-notaris di Indonesia.

Secara umum, terdapat dua aliran dalam praktik kenotariatan, Notaris Latin yang mengadopsi civil law system dan Notaris Anglo Saxon mengadopsi sistem hukum khusus common law system sehingga tidak bisa dicampuradukkan. Perbedaan antar aliran itu terletak pada fungsi yang dijalankan masing-masing notaris. Notaris Latin adalah satusatunya pejabat negara yang berhak mengeluarkan akta autentik. Sedangkan Notaris Anglo Saxon adalah notaris yang hanya mengeluarkan akta di bawah tangan yang tidak bernilai di pengadilan.

Sementara menurut Izenic, sebagaimana dikutip oleh Komar Andasasmita dan dikutip kembali oleh Habib Adjie, bentuk atau corak notaris dapat dibagi menjadi dua kelompok utama, yaitu:

1) Notariat Functionnel Dalam mana wewenang-wewenang pemerintah didelegasikan (gedelegeerd) dan demikian diduga mempunyai kebenaran isinya, mempunyai kekuatan bukti formal, dan mempunyai

11 Nusyirwan, Membedah Profesi Notaris, (Bandung: Universitas Padjadjaran,

${ }^{12}$ Ensiklopedi Nasional Indonesia, (Jakarta: Delta Pamungkas, 2004), hal 472, 
daya/ kekuatan eksekusi. Di negara-negara yang menganut macam/ bentuk notariat seperti ini terdapat pemisahan yang keras antara "wettelijke" dan "niet wettelijke" werkzaamheden, yaitu pekerjaanpekerjaan yang berdasarkan undang-undang/ hukum dan yang tidak/ bukan dalam notariat,

2) Notariat Profesional Dalam kelompok ini walaupun pemerintah mengatur tentang organisasinya, akta-akta notaris itu tidak mempunyai akibat-akibat khusus tentang kebenarannya, kekuatan bukti, demikian pula kekuatan eksekutorialnya. Konsep pengembangan undang-undang dan peraturan kenotariatan di sebuah negara harus mengacu pada konsep besar mazhab kenotariatan ini karena masing-masing memiliki landasan filosofi hukum yang berbeda. ${ }^{13}$

Deskripsi itu menunjukkan bahwa kedudukan notaris itu strategis. Campur tangan atau "intervensi" negara (pemerintah) dalam mengatur kewenangan dan penempatan notaris merupakan salah satu bukti, bahwa kehadiran notaris selain sangat dibutuhkan oleh masyarakat, juga harus mendapatkan pengaturan secara khusus dari negara (pemerintah). Bagaimanapun juga, kewenangan yang dilakukan oleh notaris ini menjadkan masyarakat sebagai "obyek" kerjanya secara yuridis, yang diniscayakan dapat mengundang kompetisi antar notaris, sehingga harus diatur kepastian aktifitasnya.

\section{KESIMPULAN}

Kedudukan notaris sangat strategis, karena notaris adalah pejabat umum yang diangkat oleh pemerintah atau negara, disamping mempunyai kewenangan dalam membuat atau menerbitkan akta autentik, sehingga logis sekal jika banyak yang berkeinginan menempuh jalur profesi sebagai notaris. Kewenangan strategis merupakan standar, bahwa siapapun yang menjadi notaris dituntut mempunyai kasitas keilmuan dan etika.

Akta autenik yang dibuat oleh notaris inilah yang membuat notaris menjadi salah satu pelaksana profesi hukum yang banyak berpengaruh terhadap banyak hal yang berhubungan dengan dunia hukum dan layanan masyarakat. Kewenangan notaris ini pula yang membuat masyarakat, khususnya para pemohon layanan jasa bergantung pada pelaksanaan profesinya atau penuntasan .

${ }^{13}$ Habib Adjie, Meneropong Khazanah Notaris \& PPAT Indonesia (kumpulan tulisan tentang Notaris dan PPAT), (Bandung: Citra ADitya Bakti, Bandung, 2009), hal. 12 


\section{DAFTAR PUSTAKA}

\section{Buku}

Ensiklopedi Nasional Indonesia, 2004, Jakarta: Delta Pamungkas.

G.H.S. Lumban Tobing, 1980, Peraturan Jabatan Notaris (Notaris Reglement), Jakarta: Erlangga. 1983, Peraturan Jabatan Notaris, cet. 3, Jakarta:

\section{Erlangga.}

Habib Adjie, 2009, Meneropong Khazanah Notaris \& PPAT Indonesia (kumpulan tulisan tentang Notaris dan PPAT), Bandung: Citra ADitya Bakti, Bandung.

Hizbul Maulana, 2015, Masyarakat Indonesia Membutuhkan Notaris Jakarta: Primamedia.

K. Kholilurrahman, 2013, Membangun Penegakan Hukum yang Beradab, Jakarta: Tinta Mas.

Lembaga Penelitian UB, 2009, Konstruksi Perwakilan Daerah Dalam Sistem Ketatanegaraan Indonesia, Kerjasama DPD RI dan Universitas Brawijaya, Malang: Pusat Pengkajian Konstitusi Fakultas Hukum Universitas Brawijaya, 2009.

Nusyirwan, 2000, Membedah Profesi Notaris, (Bandung: Universitas Padjadjaran.

Soerjono Soekanto, 1988, Faktor-faktor yang Mempengaruhi Penegakan Hukum di Indonesia, Jakarta: Rajawali Pres.

\section{Peraturan Perundang-undangan}

Undang-Undang Republik Indonesia Nomor 30 Tahun 2004 Tentang Jabatan Notaris

Undang-Undang Republik Indonesia Nomor 2 Tahun 2014 Tentang Perubahan Atas Undang-Undang Nomor 30 Tahun 2004 Tentang Jabatan Notaris 